\title{
Sposób określenia inkasenta przy poborze opłaty targowej w miastach na prawach powiatu - praktyka i problemy prawne
}

\author{
Method of determining the collector of payment \\ levying a market fee in cities with county - \\ practice and legal problems
}

Streszczenie. Opłata targowa ukształtowana została w ustawie z dnia 12 stycznia 1991 r. o podatkach i opłatach lokalnych. Jednym z najistotniejszych, lecz pomijanym w piśmiennictwie aspektem tejże opłaty, są kwestie związane z jej poborem, który najczęściej dokonywany jest $\mathrm{w}$ drodze inkasa. Celem niniejszego artykułu jest zaprezentowanie instytucji inkasenta opłaty targowej w miastach na prawach powiatu. Analiza zostaje dokonana poprzez systematyczne zestawianie unormowań prawnych kształtujących tę funkcję ze stanowiskiem doktryny oraz orzecznictwem. Z przeprowadzonej analizy wynika, że w dominującej większości przypadków praktyka działań organów jednostek samorządu terytorialnego 
w zakresie powoływania oraz regulowania zasad działania inkasentów jest prawidłowa.

Słowa kluczowe: opłata targowa; inkasent; miasta na prawach powiatu; podatki i opłaty lokalne; pobór w drodze inkasa.

\begin{abstract}
Market charge is considered as one of the local taxes and fees. One of the most important, but usually overlooked in the literature aspect of that charge are the issues related to its charging, which usually is made by way of collection. The main purpose of this article is to present institutions of market charge collectors in cities with county rights. The analysis is based on a systematic compilation of legal norms which shape the function with the position of the doctrine and case law. The article ends concludes with a summary, which synthetically recognizes the most important conclusions of the article, and lead to a submission that in most cases the practice of the authorities of local government units in terms of appointing and regulating the principles of collectors is correct.
\end{abstract}

Keywords: market charge; market fee; collector; cities with county; local duties and fees; collection charging.

\title{
1. Wprowadzenie
}

Opłata targowa jako danina publiczna została w Polsce wprowadzona ustawą z dnia 26 lutego 1951 r. o podatkach terenowych ${ }^{1}$ i funkcjonowała początkowo pod nazwą ,podatek targowy”. Aktualnie jest uregulowana w ustawie z dnia 12 stycznia 1991 r. o podatkach i opłatach lokalnych ${ }^{2}$. Przez lata obowiązywania była kilkukrotnie modyfikowana. Jedną z najistotniejszych zmian była ta uwzględniająca zmiany przepisu art. 15 ust. 1 u.p.o.l. dokonane art. 9 pkt 10 ustawy z dnia 25 czerwca 2015 r. o zmianie ustawy o samorządzie gminnym oraz niektórych innych ustaw ${ }^{3}$, która pozwoliła samorządom na samodzielne podjęcie decyzji w kwestii wprowadzenia opłaty targowej. Zmiany te były rezultatem dyskusji na temat omawianej daniny i jej charakteru. Z jednej bowiem strony, zwolnienie

\footnotetext{
Dz.U. Nr 14, poz. 110.

Tekst jedn. Dz.U. z 2016 r. poz. 716, dalej: u.p.o.l.

Dz.U. z 2015 r. poz. 1045.
} 
z opłaty targowej może przyczynić się do rozwoju drobnej przedsiębiorczości, tak cennej w lokalnym środowisku, z drugiej jednak strony, sprawny i efektywny pobór opłaty targowej może przysporzyć zauważalnego udziału w budżecie jednostki samorządu terytorialnego. Wskazać jednak należy, że tylko nieliczne jednostki zdecydowały się na rezygnację z tej opłaty.

Szczególny charakter tej daniny wskazywany jest przez doktrynę, ponieważ nie wpisuje się w ramy schematu typowej opłaty, lecz liczni autorzy zwracają uwagę na jej podobieństwo do podatku ${ }^{4}$. Należy również zaznaczyć, że opłata targowa może odgrywać istotną rolę w pobudzaniu lokalnej aktywności gospodarczej oraz porządkowaniu ruchu targowiskowego ${ }^{5}$.

W artykule prezentowany jest sposób, w jaki ukształtowana została instytucja inkasenta w polskich miastach na prawach powiatu. Będąca przedmiotem analizy praktyka samorządów wskazuje, że samorządy upodobały sobie formę poboru opłaty targowej w drodze inkasa. Na uwagę więc zasługuje fakt, że bez inkasentów nie byłby możliwy jej pobór. Celem niniejszego artykułu jest zaprezentowanie oraz zbadanie rzadko poruszanego w piśmiennictwie zagadnienia, jakim jest instytucja inkasenta opłaty targowej. Warto zastanowić się nad tym zagadnieniem nie tylko ze względu na ogromną rolę inkasenta w poborze tej opłaty, lecz także ze względu na fakt, iż funkcja ta nie została szczegółowo uregulowana w drodze ustawy. Pomimo tego, że istnieje szereg przepisów, które określają charakter inkasenta, wiele jego cech zostało ukształtowanych drodze praktyki. W rezultacie doktryna i orzecznictwo wypełniły ustawowe ramy i razem stanowią obraz ostatecznej postaci instytucji inkasenta opłaty targowej. Prezentowany artykuł kompleksowo przedstawia zagadnienie, systematycznie zestawiając praktykę działania samorządów z prawnymi podstawami oraz orzecznictwem sądów i właściwych organów kontrolujących. Za reprezentatywną grupę uznano miasta na prawach powiatu, których w Polsce obecnie jest 66. Miasta te stanowią bardzo interesujący temat do badań, ponieważ należą do grona największych ośrodków miej-

\footnotetext{
R. Mastalski., E. Fojcik-Mastalska, Prawo finansowe, Warszawa 2013, s. 365.

K. Bełus, Analiza gospodarki finansowej gminy: na przykładzie gminy Miedziana Góra, Kraków 2015, s. 42.
} 
skich w Polsce, co oznacza, że ze względu na mnogość podmiotów oferujących produkty, byt targowisk oraz inkasentów opłaty targowej jest zagrożony. Nie bez znaczenia pozostaje również fakt, że analizując uchwały miast na prawach powiatu, badaniu podlega obszar całej Polski, co czyni badanie uniwersalnym w skali całego kraju. W artykule wykorzystano metodę prawno-dogmatyczną celem zdekodowania norm prawnych, a także prawno-porównawczą oraz analityczną. Zaprezentowane dane stanowią rezultat analizy kilkudziesięciu uchwał samorządu terytorialnego oraz licznego orzecznictwa. W pracy wykorzystano również metodę historyczną celem ukazania ogólnej tendencji ewolucji tej daniny.

\section{Charakter prawny opłaty targowej}

Opłata targowa zaliczana jest do opłat lokalnych, czyli do rodzaju daniny publicznej o charakterze pozapodatkowym, związanej z czynnościami urzędowymi ${ }^{6}$. Opłaty lokalne, podobnie jak podatki, są świadczeniami pieniężnymi, bezzwrotnymi i przymusowymi. Jednak cechą odróżniającą opłatę od podatku jest ekwiwalentność świadczenia ${ }^{7}$. Jak uważają R. Mastalski i E. Fojcik-Mastalska, brak tej cechy w przypadku opłaty targowej pozwala w rzeczywistości uznać ją za podatek ${ }^{8}$. Na zasadzie podobieństwa należy również przytoczyć stanowisko A. Borodo, który opłatę targową uznaje za uproszczony podatek, związany z dokonywaniem sprzedaży ${ }^{9}$. W literaturze ${ }^{10}$ wskazuje się także, że nie stanowi to kwestii pewnej, ponieważ możliwe jest również stanowisko, iż opłata targowa stanowi formę uproszczonego podatku obrotowego, co nie zmienia oceny, że niewątpliwie świadczenie posiada charakter podatkowy. Z uwagi na charakter tej daniny za zasadne należy uznać stosowanie pojęć uregulowanych

\footnotetext{
6 Leksykon budżetowy, http://www.sejm.gov.pl/sejm7.nsf/BASLeksykon.xsp?id=A1A05A8E56ADD004C125 7A5A0022ABBF\&litera=O (dostęp: 20.07.2016 r.).

Tamże.

R. Mastalski E. Fojcik-Mastalska, Prawo..., s. 365.

A. Borodo, Polskie prawo finansowe, Toruń 2014, s. 174.

10 W. Morawski, J. Wantoch-Rekowski, Opłata targowa [w:] W. Morawski (red.), Komentarz do ustawy o podatkach i opłatach lokalnych, Gdańsk 2009, s. 745.
} 
w art. 4 i 5 ustawy z dnia 29 sierpnia 1997 r. - Ordynacja podatkowa ${ }^{11}$, tj. „obowiązek podatkowy” i „zobowiązanie podatkowe”12. Danina ta ma charakter podatku powiązanego ze sprzedażą towarów i usług na targowisku. Jak stanowi art. 15 ust. 3 u.p.o.l., opłata targowa pobierana jest niezależnie od należności za korzystanie z urządzeń targowych oraz za inne usługi świadczone przez prowadzącego targowisko. Szczegółowa konstrukcja opłaty targowej pozostawiona została do uregulowania przez radę gminy w drodze uchwały. Stanowisko, by uznać opłatę targową za podatek, wyrażają też T. Wołowiec i D. Reśko stwierdzając, że „(...) opłatę targową należy uznać za typowy podatek. Odpowiada ona definicji podatku wskazanej w art. 6 o.p., zgodnie z którą podatkiem jest publicznoprawne, nieodpłatne, przymusowe oraz bezzwrotne świadczenie pieniężne na rzecz Skarbu Państwa, województwa, powiatu lub gminy, wynikające z ustawy podatkowej."13 Autorzy swoje stanowisko uzasadniają faktem, że obowiązek uiszczania tej opłaty nie zależy od żadnych wzajemnych świadczeń gminy na rzecz kupców sprzedających na targowiskach, a także, że pobór opłaty targowej jest niezależny od innych opłat za korzystanie z urządzeń targowych lub też konieczności ponoszenia kosztów za usługi świadczone przez prowadzącego targowiska ${ }^{14}$.

\section{Pobór opłaty targowej w drodze inkasa}

Analizę przedmiotowej kwestii należy zacząć od stwierdzenia, że Rada Miasta wraz z uchwaleniem wysokości opłaty targowej może zarządzić pobór opłaty targowej w drodze inkasa. Wskazać tu należy, jak słusznie zauważył P. Mańczyk: „Wprowadzenie w danej gminie inkasa podatków i opłat lokalnych nie odbiera podatnikowi możliwości realizacji zobowiązania podatkowego poprzez zapłatę należności bezpośrednio na rzecz organu podatkowego, z pominięciem inkasenta. Inkaso jest jedynie dodat-

\footnotetext{
Tekst jedn. Dz.U. z 2015 r. poz. 613 ze zm., dalej: o.p.

W. Morawski, J. Wantoch-Rekowski, Opłata..., s. 745.

13 T. Wołowiec, D. Reśko, Opłata targowa a sprzedaż w miejscach, w których prowadzony jest handel, „Finanse Komunalne” 2011, nr 10, s. 32.

14 T. Wołowiec, D. Reśko, Opłata..., s. 34.
} 
kową możliwością wywiązania się przez podatnika z ciążącego na nim obowiązku podatkowego. Organy podatkowe nie mogą ograniczać sposobów, w jaki podatnik może dokonać zapłaty podatku. Ograniczenie możliwości zapłaty podatku jedynie do jego poboru przez inkasenta należy uznać za niezgodne z prawem.”15

Zgodnie z art. 9 o.p. inkasent to osoba fizyczna, osoba prawna lub jednostka organizacyjna nieposiadająca osobowości prawnej obowiązana do pobrania podatku od podatnika oraz wpłacenia go organowi podatkowemu we właściwym terminie. Odnosząc się do poglądu wyrażonego przez K. Stelmaszczyk ${ }^{16}$, wykładnia przepisów wskazujących na zakres prawnych kompetencji rady gminy do wyznaczenia w drodze podjętej uchwały inkasentów podatków i opłat lokalnych nie powinna mieć podstawy wyłącznie w przepisach materialnych ustaw podatkowych, determinujących poszczególne tytuły podatkowe. Wykładnia powinna uwzględniać również art. 9 o.p., określający podmiotowość prawnopodatkową inkasenta.

\section{Inkasenci opłaty targowej}

W zakresie opłaty targowej, stanowiącej dochód budżetu gminy, funkcja inkasenta występuje wyłącznie w przypadku zarządzenia poboru tejże opłaty w drodze inkasa - zarządzenie to stanowi jedynie uprawnienie właściwego organu, a nie obowiązek nałożony przez przepisy prawa. Upoważnionym do tego organem jest rada gminy, która stosownie do art. 19 pkt 2 u.p.o.l. może zarządzić pobór w drodze inkasa opłaty targowej. Uprawniona jest również do określenia inkasentów oraz wysokości wynagrodzenia za inkaso. Praktyka w miastach na prawach powiatu kształtuje się różnorodnie. W większości przypadków inkasenci zostali ustanowieni

15 P. Mańczyk, Pobór podatku od nieruchomości oraz opłaty targowej, miejscowej, uzdrowiskowej $i$ od posiadania psów $w$ drodze inkasa na przykładzie wybranych gmin województwa, „Acta Iuris Stetinensis” 2014, nr 5, s. 393-406, dostęp: 08.08 .2016 r.: http://wpiaus.pl/actaiuris/files/23---Ma-czyk---Pobor-podatku....pdf, s. 395.

16 K. Stelmaszczyk, Glosa do wyroku Wojewódzkiego Sq̨u Administracyjnego w Lublinie z 25.04.2014 r., I SA/Lu 133/14. Zakres prawnych kompetencji rady gminy do wyznaczenia inkasentów podatków i opłat lokalnych, „Finanse Komunalne” 2015, nr 11, s. 75-79. 
w tej samej uchwale wprowadzającej opłatę targową. Kilkukrotnie inkasenci zostali powołani w drodze odrębnej uchwały.

Jedną z kwestii wartych rozważenia są przesłanki nabycia statusu inkasenta opłaty targowej. Z orzecznictwa wynika, że do wejścia w obowiązki i uprawnienia podmiotów zobowiązanych na podstawie prawa podatkowego do określonych obowiązków i uprawnień, w tym przypadku inkasentów opłaty targowej, nie wystarczy zawarcie przez podmioty umowy cywilnoprawnej z zarządem gminy na pobór opłaty targowej. Nawet odwołanie się w umowie do przepisów o.p. w sprawach nieuregulowanych nie spowoduje nabycia przez podmiot statusu inkasenta. Inkasentów bowiem wyznacza się na podstawie przepisów ustawy, a zatem do nabycia tego statusu konieczne jest wydanie przez radę gminy uchwały. Zgodnie natomiast z art. 18 ust. 2 pkt 8 ustawy z dnia 8 marca 1990 r. o samorządzie gminnym ${ }^{17}$ podejmowanie uchwał w sprawie opłaty targowej należy do wyłącznej kompetencji rady gminy, a co za tym idzie, nie jest możliwe przekazanie tej kompetencji innemu organowi. Przykładem naruszenia wspomnianego przepisu jest określenie inkasenta jako Urzędu Gminy. W tej sytuacji wyznaczenie osoby pobierającej w imieniu inkasenta opłatę targową należałoby do obowiązków kierownika jednostki, co faktycznie powoduje przekazanie uprawnień do określania inkasentów innemu niż rada gminy podmiotowi ${ }^{18}$. Spowoduje to wadliwość uchwały rady gminy $\mathrm{w}$ sprawie wyznaczenia inkasenta $\mathrm{z}$ uwagi na fakt, iż tak sformułowany przepis nie określa, na kim ciążą obowiązki ustawowo przypisane inkasentom $^{19}$. W praktyce w przypadku kilku miast na prawach powiatu można zaobserwować wyznaczenie inkasentów we wskazany powyżej, wadliwy sposób. Przykładowo, w Bielsku-Białej ${ }^{20}$ Urząd Miejski został wskazany jako inkasent na targowiskach zlokalizowanych przy wskazanych w uchwale ulicach oraz „w pozostałych miejscach”. Z sytuacją

\footnotetext{
Dz.U. z 2016 r. poz. 446.

18 Uchwała Regionalnej Izby Obrachunkowej w Poznaniu z dnia 28 września 2005 r., 22/594/2005.

19 Uchwała Regionalnej Izby Obrachunkowej we Wrocławiu z dnia 30 listopada 2011 r., 100/2011.

20 Uchwała nr XIII/202/2015 Rady Miejskiej w Bielsku-Białej z dnia 24 listopada 2015 r. w sprawie opłaty targowej.
} 
określenia jako inkasenta urzędu można się spotkać również w przypadku Zielonej Góry $^{21}$, w Świnoujściu ${ }^{22}$, Koninie ${ }^{23}$, Lesznie $^{24}$, Chorzowie $^{25}$.

\title{
5. Forma prawna inkasenta
}

Analizując zagadnienie inkasenta opłaty targowej, nie można pominąć praktycznego aspektu podmiotowości inkasenta. Z analizowanych uchwał wynika, że w dominującej większości przypadków zadanie inkasenta wypełniają podmioty zorganizowane, np. stowarzyszenia i spółki. Drugą pozycję pod względem liczności zajmują osoby fizyczne. Natomiast jedynie co piątym inkasentem ustanowiono jednostkę zależną od organu gminy. Dane obrazujące powyższe zagadnienie zostały zaprezentowane na poniższym wykresie.

Wykres 1. Podmioty wskazane jako inkasenci opłaty targowej.

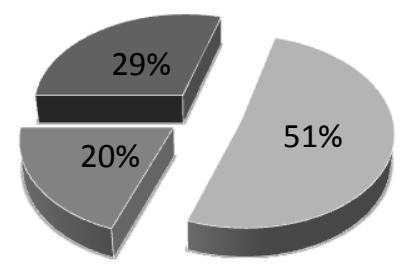

\author{
- Osoba fizyczna \\ - Osoba prawna \\ - Jednostka zależna od \\ organu gminy
}

Źródło: Opracowanie własne na podstawie danych zebranych w drodze analizy uchwał.

21 Uchwała nr LXI/769/10 Rady Miasta Zielona Góra z dnia 23 lutego 2010 r. w sprawie zarządzenia poboru opłaty targowej w drodze inkasa.

22 Uchwała nr XVI/118/2015 Rady Miasta Świnoujście z dnia 26 listopada 2015 r. w sprawie opłaty targowej.

23 Uchwała nr 222 Rady Miasta Konina z dnia 25 listopada 2015 r. w sprawie opłaty targowej.

24 Uchwała nr XIV/174/2015 Rady Miejskiej Leszna z dnia 26 listopada 2015 r. w sprawie opłaty targowej, Dz.Urz. Województwa Wielkopolskiego, poz. 8216.

25 Uchwała nr XIV/250/15 Rady Miasta Chorzów z dnia 29 października 2015 r. w sprawie opłaty targowej obowiązującej na terenie miasta Chorzów. 
Zgodnie z tezą Naczelnego Sądu Administracyjnego wyrażoną w wyroku z dnia 11 stycznia 2008 r. $^{26}$ wskazanie inkasenta powinno przybierać postać określenia konkretnego, a więc zwrotu odnoszącego się do zindywidualizowanego przez podanie imienia i nazwiska podmiotu (w przypadku osoby prawnej lub jednostki organizacyjnej niemającej osobowości prawnej - nazwy). Natomiast jak stwierdził Naczelny Sąd Administracyjny w wyroku z dnia 11 marca 1994 r.: „Przewidziana w art. 19 w związku z art. 15 ustawy z 12.1.1991 r. o podatkach i opłatach lokalnych (...) delegacja do określania przez rady gmin zasad ustalania i poboru oraz wysokości stawek opłaty targowej nie obejmuje upoważnienia do ustanawiania zasad odpowiedzialności inkasentów i zarządców targowisk za nierozliczenie się z pobranych opłat organami gminy”27. W praktyce najczęściej jedno miasto powołuje kilku inkasentów i przydziela im rewiry. Przykładowo można wskazać Gorzów Wielkopolski ${ }^{28}$, gdzie Ośrodek Sportu i Rekreacji w Gorzowie Wlkp. pełni funkcję inkasenta na targowiskach przy ul. Szczecińskiej, natomiast na pozostałych targowiskach w obrębie miasta inkasentem jest Gorzowski Rynek Hurtowy Spółka Akcyjna w Gorzowie Wlkp.

Status inkasenta powinien mieć źródło w akcie prawa miejscowego, tj. w uchwale rady gminy wydanej na podstawie ustawowego upoważnienia $^{29}$. Z uchwały rady gminy w sprawie określenia inkasenta powinno wynikać, kto faktycznie jest inkasentem, poprzez wskazanie cech pozwalających na jego dostateczne zindywidualizowanie. Inkasent może być zatem wymieniony z imienia i nazwiska lub nazwy, gdy wskazana zostaje osoba prawna lub jednostka organizacyjna nieposiadająca osobowości prawnej, albo też wskazany poprzez określenie pełnionej funkcji tak, by wskazanie konkretnej osoby utożsamianej ze wspomnianą funkcją nie budziło wątpliwości. Tylko wtedy bowiem uchwała będzie pełnić funkcje gwarancyjne, pozwoli na ustalenie nieokreślonych ustawą kwestii doty-

\footnotetext{
Wyrok NSA z dnia 11 stycznia 2008 r., II FSK 1526/06, Legalis.

Wyrok NSA z dnia 11 marca 1994 r., SA/WR 185/94, „Monitor Podatkowy” 1994, nr 8, s. 242.

28 Uchwała Nr XX/246/2015 Rady Miasta Gorzowa Wlkp. z dnia 21 grudnia 2015 r.

29 Wyrok NSA z dnia 21 września 2007 r., FSK 1008/06, CBOSA.
} 
czących praw i obowiązków zainteresowanych podmiotów ${ }^{30}$. Realizacja uprawnień rady gminy w zakresie wyznaczania inkasenta winna nastąpić w uchwale w sposób precyzyjny, kryterium identyfikacji ma więc zasadnicze znaczenie przy określeniu podmiotu mającego pełnić funkcję inkasenta $^{31}$. W orzecznictwie wskazuje się jednak przypadki, w których wystarczające jest skonkretyzowanie inkasenta poprzez określenie cech, które indywidualizują go w sposób odpowiedni do daniny, którą ma pobrać, np. w przypadku opłaty miejscowej: „ustanowienie inkasentem każdego, kto umożliwia osobie fizycznej pobyt dłużej niż dobę, poprzez udostępnienie zakwaterowania" ${ }^{32}$. Zdaje się jednak, że należy zachować ostrożność przy „niedookreślaniu” inkasenta w uchwale, gdyż możliwość dokładniejszego lub też mniej dokładnego wskazania inkasenta jest zależna od specyfiki konkretnej daniny i każdy przypadek należy rozpatrywać indywidualnie.

Istotnym problemem praktycznym zdaje się być kwestia zgody osoby, którą określa się jako inkasenta. Mimo iż ustawodawca używa w art. 19 pkt 2 u.p.o.l. jedynie sformułowania „określić inkasentów”, to w orzecznictwie znaleźć można pogląd, jakoby powierzenie komuś stanowiska inkasenta wymagało uprzedniej zgody tego podmiotu. Zgoda na przyjęcie obowiązków łączących się z pełnieniem funkcji inkasenta winna być wyrażona przed wyznaczeniem inkasenta, a także przed zawarciem stosownej umowy, która ma wyłącznie techniczny charakter ${ }^{33}$.

$\mathrm{Na}$ bardzo istotną kwestię zwrócił uwagę L. Etel, a mianowicie na konieczność nałożenia na inkasentów opłaty targowej odpowiedzialności za niepobrane opłaty: „(...) w chwili obecnej inkasent wskazany w uchwale rady gminy może nie pobierać podatków i opłat i nie ponosić $\mathrm{z}$ tego tytułu żadnej odpowiedzialności (ani na gruncie ordynacji podatkowej, ani na gruncie kodeksu karnego skarbowego)"34. Niejednokrotnie może się zdarzyć, że następstwem takiego ukształtowania prawnego instytucji inka-

\footnotetext{
Wyrok WSA w Gliwicach z dnia 15 maja 2014 r., I SA/Gl 1757/13, Legalis.

Wyrok WSA w Olsztynie z dnia 5 marca 2015 r., II SA/Ol 79/15.

Wyrok WSA w Olsztynie z dnia 25 lutego 2015 r., I SA/Ol 56/15, Legalis.

Wyrok WSA w Łodzi z dnia 10 października 2013 r., I SA/Łd 922/13, Legalis.

L. Etel, R. Dowgier, Podatki i opłaty lokalne - czas na zmiany, Białystok 2013, s. $104-105$.
} 
senta jest uniemożliwienie realizacji świadczenia, a w rezultacie uszczuplenie wpływów budżetowych.

\section{Wynagrodzenie za inkaso - teoria}

Rada gminy, stosownie do art. 28 § 4 o.p., może ustalać wynagrodzenie dla inkasentów z tytułu poboru podatków stanowiących dochody budżetu gminy. Jeżeli rada gminy skorzysta ze swojego uprawnienia i zarządzi pobór opłaty targowej w drodze inkasa, zobowiązana jest jednocześnie do określenia wynagrodzenia za inkaso. Niedopuszczalnym jest zapis stanowiący, iż rada gminy wyznacza inkasenta, ale nie ustala wynagrodzenia za inkaso. Zgodnie z analizą przeprowadzoną przez Kolegium Regionalnej Izby Obrachunkowej w Warszawie $^{35}$ ustawodawca nieprzypadkowo w przepisie art. 19 pkt 2 u.p.o.l. zastosował koniunkcję w postaci „Rada gminy, w drodze uchwały: (...) może zarządzić pobór tych opłat w drodze inkasa oraz określić inkasentów i wysokość wynagrodzenia za inkaso (...)”. Przepis ten jest przepisem o charakterze ius cogens i rada gminy jest zobligowana do ustalenia wysokości wynagrodzenia za inkaso. Odmienne stanowisko zajął w tej kwestii Wojewódzki Sąd Administracyjny w Opolu ${ }^{36}$, wskazując, iż „(...) kompetencja do ustalenia wynagrodzenia została przyznana organom stanowiącym jednostek samorządu terytorialnego wszystkich szczebli” - obecnie tylko gmina ma własne podatki, stąd nie ma ona obowiązku określenia w drodze uchwały wysokości wynagrodzenia za inkaso, choć ma taką możliwość. W praktyce jednak można zaobserwować, że dominuje wykładnia dokonana przez Kolegium Regionalnej Izby Obrachunkowej. W reprezentatywnej grupie w przypadku wszystkich uchwał zostało wskazane wynagrodzenie za inkaso.

W kwestii wynagrodzenia inkasenta warto zwrócić uwagę na fakt, iż przepisy u.p.o.l. uprawniają radę gminy również do ustalenia wysokości wynagrodzenia za inkaso. Istotnym jest również, że rada może zmienić

35 Uchwała Regionalnej Izby Obrachunkowej w Warszawie z dnia 28 lutego 2012 r., sygn. 5.87.2012.

36 Wyrok WSA w Opolu z dnia 14 lipca 2009 r., I SA/Op 277/09, Legalis. 
ustaloną przez siebie wysokość wynagrodzenia inkasenta, nie wiąże ona rady na zawsze (Wyrok NSA z dnia 27 stycznia 1995 r.) ${ }^{37}$.

Wynagrodzeniem za inkaso mogą zostać objęte jedynie czynności wynikające z obowiązków inkasenta opłaty targowej, a zatem pobranie opłaty i wpłacenie jej organowi podatkowemu, o czym stanowią art. 19 pkt 2 u.p.o.l. oraz art. 9 o.p. Nie jest możliwe objęcie wynagrodzeniem za inkaso takich czynności jak sprzątanie i odśnieżanie placu targowego czy utrzymanie czystości w sanitariacie. Jak wynika z Uchwały Kolegium RIO w Rzeszowie z dnia 15 grudnia 2009 r. $^{38}$, rozszerzenie katalogu czynności objętych wynagrodzeniem za inkaso stanowić będzie istotne naruszenie dyspozycji wspomnianych ustaw. Ocena, jak ten warunek jest przestrzegany w rzeczywistości, jest bardzo trudna. Z materiałów, które udało się zebrać w ramach przeprowadzonego projektu badawczego, wynika jednak, że przynajmniej na poziomie uchwał wprowadzających wskazany powyżej warunek jest respektowany.

Jak wskazuje P. Mańczyk, wysokość wynagrodzenia dla inkasenta z tytułu wykonywanych przez niego obowiązków może być ustalona w dowolny sposób. Najczęściej wynagrodzenie stanowi określony procent od pobranych i wpłaconych danin, jednak można inkasentowi przyznać stałą kwotę wynagrodzenia, określić je w sposób mieszany (procentowo i ponadto jakaś stała kwota) lub przyznać wprawdzie wynagrodzenie procentowe, ale zastrzec, że nie może ono być niższe lub wyższe od jakiejś kwoty.

\section{Wynagrodzenie za inkaso - praktyka}

Na ciekawą kwestię zwrócili uwagę T. Wołowiec i D. Reśko, mianowicie na to, że obowiązek uiszczenia opłaty targowej powstaje w każdym dniu, w którym podmiot dokonuje sprzedaży na targowisku. W tym też dniu podatnik powinien uiścić należną opłatę. Konsekwencją powyższego jest fakt, że organy podatkowe nie mogą żądać uiszczenia należnej opłaty

Sygn. SA/Rz 75/94, CBOSA.

XXVII/8229/2009. 
z góry, czyli wprowadzić tzw. opłaty zryczałtowanej (abonamentowej) za określony czas $^{39}$. Przeprowadzone badania wykazały, że w tej kwestii praktyka jest właściwa i w żadnej ze zbadanych uchwał nie wprowadzono ryczałtu.

W przedmiotowej kwestii praktyka w badanych uchwałach nie cechuje się zbytnią różnorodnością. Wynagrodzenie za inkaso we wszystkich przypadkach zostało określone jako procent od pobranej kwoty. Zdaje się, że jest to dobre rozwiązanie, profiskalne, gdyż stanowi swoisty system motywacyjny dla inkasentów, którzy chcąc uzyskać jak największą korzyść dla siebie, muszą być efektywni w wykonywaniu swoich obowiązków. Wskazać przede wszystkim należy rozbieżności w wysokościach opłaty za inkaso, które ukształtowane zostały w wysokości od $10 \%$ do 95\% (Zakład Gospodarki Lokalowej Spółka z o.o. w Białej Podlaskiej). Powyższe ocenić należy w powiązaniu z celami, na jakie opłata targowa jest przeznaczana przez samorządy. Zaznaczyć bowiem należy, że opłata targowa nie ma charakteru celowego - może zostać przeznaczona na wykonanie zadania samorządu terytorialnego w postaci zapewnienia targowiska, może być również wydatkowana na inny cel.

Największe rozbieżności w wysokości ustalonych wynagrodzeń za inkaso można zaobserwować w Koszalinie ${ }^{40}$, gdzie w zależności od miejsca, w którym inkaso jest pobierane (a jednocześnie w zależności od inkasenta, gdyż w każdym miejscu jest ustalony inny inkasent), wysokości wynagrodzenia kształtują się od 8 do aż 85\%. Zauważyć należy, że wysokość wynagrodzenia zróżnicowana jest nie tylko w zależności od miasta na prawach powiatu, ale także wewnętrznie, w obrębie jednego miasta na prawach powiatu. Z interesująco ustalonym wynagrodzeniem mamy do czynienia w przypadku Konina ${ }^{41}$, gdzie wynosi tylko symboliczny $1 \%$. Zauważalne są przypadki miast, w których wynagrodzenie inkasenta zostało ustalone w symbolicznej, bądź też, z drugiej strony, w wysokości

39 T. Wołowiec, D. Reśko, Opłata..., s. 34.

40 Uchwała nr XV/187/2015 Rady Miejskiej w Koszalinie z dnia 26 listopada 2015 r. w sprawie wprowadzenia opłaty targowej, ustalenia jej wysokości oraz sposobu poboru.

41 Uchwała nr 222 Rady Miasta Konina z dnia 25 listopada 2015 r. w sprawie opłaty targowej. 
prawie równej wysokości pobranej opłaty targowej. Odnosząc się jednak do praktyki, którą można określić na podstawie informacji wynikających $\mathrm{z}$ uchwał rad miast w sprawie opłaty targowej w miastach na prawach powiatu, procentowa stawka wynagrodzenia inkasenta wyliczona na podstawie średniej arytmetycznej wynosi w przybliżeniu 33\%. Najniższe stawki wynoszą $0 \% \mathrm{w}$ Tarnowie oraz $1 \%$ pobranej opłaty targowej w Koninie. 90\% sumy opłat pobranych i terminowo przekazanych w Zabrzu oraz 95\% w Białej Podlaskiej stanowią najwyższe procentowo określone wynagrodzenie inkasenta opłaty targowej w miastach na prawach powiatu. Ze względu na swoją specyfikę do średniej arytmetycznej nie zostały wliczone stawki wynagrodzenia inkasenta w Częstochowie. Otóż Rada Miasta Częstochowy uzależniła wynagrodzenie inkasenta od kwoty opłaty targowej, i tak przykładowo stawka wynagrodzenia wynosi $1 \%$, lecz po przekroczeniu 483000 zł wynagrodzenie wzrasta o 50\% czy też wynosi 5\%, ale po przekroczeniu 662200 zł wynagrodzenie wzrasta o 50\%. Procentowo określone kwoty dookreślane są różnymi zwrotami, takimi jak: „pobranych i odprowadzonych kwot”, „pobranej i terminowo odprowadzonej opłaty”, „brutto od sumy inkasowanych kwot”, „od pobranej i odprowadzonej na rachunek budżetu miasta kwoty”.

Z ciekawie ukształtowanym wynagrodzeniem dla inkasenta mamy do czynienia w Siedlcach ${ }^{42}$, gdzie prowizja inkasenta została uzależniona od tego, czy targowisko stanowi własność komunalną, czy też prywatną. I tak, prowizja inkasenta za zebraną opłatę targową z targowisk komunalnych wynosi $60 \%$ wpływów, natomiast $\mathrm{z}$ targowisk stanowiących własność prywatną wynosi 85\% wpływów brutto.

W dosyć nietypowy sposób dla innych miast na prawach powiatu wynagrodzenie inkasenta zostało ukształtowane również w Częstochowie $^{43}$, bowiem wysokość wynagrodzenia uzależniono od tego, kto jest inkasentem (w uchwale wskazano 8 podmiotów, przykładowo wymienia-

42 Uchwała nr XIV/170/2015 Rady Miasta Siedlce z dnia 27 listopada 2015 r. znowelizowana uchwałą NR XV/180/2015 Rady Miasta Siedlce z dnia 28 grudnia 2015 r.

43 Uchwała nr 223.XIX.2015 Rady Miasta Częstochowy z dnia 30 grudnia 2015 r. w sprawie ustalenia zasad poboru, określenia inkasentów oraz ich wynagrodzenia za inkaso opłaty targowej na terenie miasta Częstochowy ze zm. 
jąc spółkę cywilną, spółkę z ograniczoną odpowiedzialnością, stowarzyszenia i inne) a także od wysokości zebranej kwoty opłaty targowej, np. wynagrodzenie za inkaso Wojewódzkiej Spółdzielni OgrodniczoPszczelarskiej na targowisku przy ul. Radomskiej wynosi 10\%, po przekroczeniu 27600 zł wynagrodzenie wzrasta o 50\%. Wskazać również należy na pewne rozbieżności w zakresie kwoty bazowej stanowiącej podstawę obliczenia wynagrodzenia inkasenta. W praktyce zastosowanie znajdują trzy sposoby - od pobranej opłaty targowej, od wpłaconej opłaty targowej lub od pobranej i wpłaconej opłaty targowej. Przeciętne wynagrodzenie za inkaso w miastach na prawach powiatu natomiast wyniosło w przybliżeniu $33 \%$.

\section{Liczba inkasentów w poszczególnych miastach}

Logicznym jest także, że w przypadku większych miast na prawach powiatu uzasadnione jest powoływanie większej liczby inkasentów. Jest to tendencja zauważalna w praktyce. Uzasadnione to jest przede wszystkim faktem znacznego rozproszenia targowisk lub też po prostu liczbą handlujących podlegających danemu inkasentowi ${ }^{44}$. W praktyce nie do zawsze zostało to zapewnione. Potwierdzone to zostało wynikami badania, które obrazuje poniższy wykres. Zauważalne jest bowiem, że praktycznie w co trzecim mieście na prawach powiatu na jednego inkasenta przypada od 50 do 100 tys. mieszkańców. Oczywiście zaznaczyć należy, że liczba mieszkańców nie jest w 100\% miarodajna w tym przypadku, jednak dla celów badań statystycznych można uznać zaludnienie miasta za wyznacznik ilości osób prowadzących sprzedaż na targowiskach. Co więcej, w przypadku prawie połowy miast na prawach powiatu na jednego inkasenta przypada co najmniej 50 tys. mieszkańców. Być może jest to przyczyna tak małego udziału opłaty targowej w budżecie, a zwiększenie liczby inkasentów opłaty targowej przyczyniłoby się do wzrostu efektywności jej poboru, a w rezultacie jej znaczenia fiskalnego.

44 P. Mańczyk, Pobór podatku..., s. 398. 
Wykres 2. Liczba mieszkańców przypadająca na jednego inkasenta.

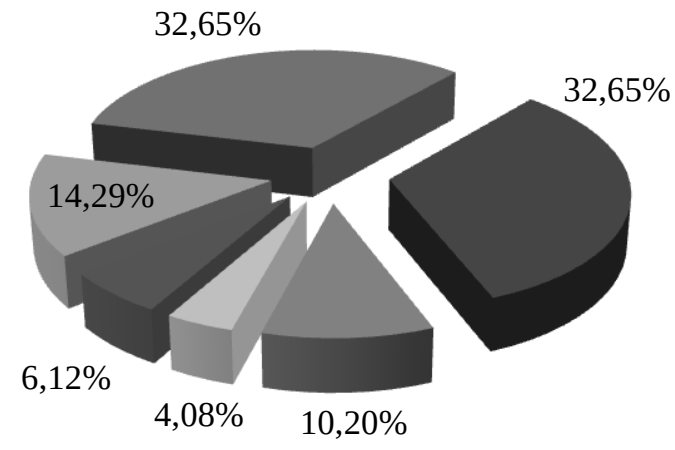

$$
\begin{aligned}
& \text { - poniżej } 10 \text { tys. } \\
& \text { 10-20 tys. } \\
& \text { 20-50 tys. } \\
& \text { - 50-100 tys. } \\
& \square \text { 100-200 tys. } \\
& \text { powyżej } 200 \text { tys. }
\end{aligned}
$$

Źródło: Opracowanie własne na podstawie danych zebranych w drodze analizy uchwał.

\section{Podsumowanie}

W rzeczywistości cechującej się zdecentralizowanym system zarządzania, wiążącym się z oddelegowaniem części uprawnień i kompetencji do ośrodków samorządowych, a także swoistym związaniem jedynie co do celu (sposób wykonania zadania jest zawężony tylko nieznacznie przez przepisy prawa), mamy do czynienia z pewną różnorodnością ukształtowania praktyki. Wskazać przede wszystkim należy zróżnicowanie w wynagrodzeniu inkasentów oraz liczby powoływanych inkasentów, w zależności od liczby mieszkańców. Zauważalne bowiem są rozbieżności w wysokości wynagrodzenia inkasentów, nawet w obrębie jednego miasta, zależnie od tego, na jakim targowisku pobierana jest opłata, oraz od tego, kto został powołany do pełnienia funkcji inkasenta. Zaznaczyć przede wszystkim należy, że praktycznie we wszystkich uchwałach zostało ustanowione wynagrodzenie dla inkasenta. Badania wykazały, że niektóre z miast zdecydowały się nagradzać inkasentów w czysto symbolicznej wysokości, inne natomiast przeznaczają dla inkasentów nawet $85 \%$ pobranej opłaty. Ma to niewątpliwie ogromne znaczenie w sferze motywacyjnej dla inkasentów. Zaznaczyć również należy, że fakt przyznania 
wyższego wynagrodzenia procentowego inkasentom nie musi oznaczać niższych wpływów do budżetu, ponieważ zachęcony wyższym zarobkiem inkasent będzie dbał o wzrost efektywności i w ten sposób będzie w większym stopniu przysparzał środków budżetowi. Różnorodnie kształtuje się również zagadnienie liczby inkasentów wyznaczonych w danych ośrodkach. Zauważalną zasadą zdaje się być zwiększona liczba inkasentów w przypadku miast na prawach powiatu charakteryzujących się wyższą liczbą mieszkańców, choć w przypadku prawie połowy miast na prawach powiatu na jednego inkasenta przypada co najmniej 50 tys. mieszkańców. Niejednokrotnie zbyt mała liczba inkasentów lub też przyznanie inkasentom opłaty targowej zbyt dużego obszaru negatywnie wpływa na wysokość wpływów budżetowych z racji poboru opłaty targowej. Zaznaczyć w tym miejscu należy, że samorządy, zwiększając liczbę inkasentów, nie odczułyby negatywnych skutków finansowych, a pozytywne, gdyż wynagrodzenie inkasenta jest uzależnione od jego efektywności. Podobieństwo dostrzegalne jest z kolei w sposobie poboru opłaty - wszystkie samorządy wybrały pobór opłaty w drodze inkasa. W niektórych tylko przypadkach naruszone zostały dyspozycje przepisów, np. poprzez wyznaczenie na inkasenta Urzędu Miasta, jednak ogół praktyki należy uznać za poprawny.

\section{Bibliografia:}

Bełus K., Analiza gospodarki finansowej gminy: na przykładzie gminy Miedziana Góra, Promotor, Kraków 2015.

Borodo A., Polskie prawo finansowe, TNOiK, Toruń 2014.

Etel L, Dowgier R., Podatki i opłaty lokalne - czas na zmiany, Wydawnictwo Temida 2, przy współpr. Wydziału Prawa Uniwersytetu w Białymstoku, Białystok 2013.

Mańczyk P., Pobór podatku od nieruchomości oraz opłaty targowej, miejscowej, uzdrowiskowej i od posiadania psów w drodze inkasa na przykładzie wybranych gmin województwa, „Acta Iuris Stetinensis” 2014, nr 5, s. 393-407.

Mastalski R., Fojcik-Mastalska E., Prawo finansowe, Wolters Kluwer business, Warszawa 2013. 
Marek Słupczewski, Olga Kosmala, Martyna Wilmanowicz

Morawski W., Wantoch-Rekowski J., Opłata targowa [w:] W. Morawski (red.), Komentarz do Ustawy o podatkach i opłatach lokalnych, ODDK, Gdańsk 2009.

Stelmaszczyk K., Zakres prawnych kompetencji rady gminy do wyznaczenia inkasentów podatków i opłat lokalnych. Glosa do wyroku Wojewódzkiego Sqdu Administracyjnego w Lublinie z 25.04.2014 r., I SA/Lu 133/14, „Finanse Komunalne” 2015, s. 75-79.

Wołowiec T., Reśko D., Opłata targowa a sprzedaż w miejscach, w których prowadzony jest handel, „Finanse Komunalne” 2011, nr 10, s. 32-36. 